\title{
Transmigrant Literature:
}

\section{Translating, Publishing, and Printing in Seventeenth-Century Frankfurt's}

\author{
Migrant Circles
}

\begin{abstract}
This article examines the role of migrant publishers in German literary culture and the book market in the seventeenth century. Focusing on Christoph Le Blon's network of secondgeneration migrant publishers, including Joachim von Sandrart, Friedrich Hulsius, and Lucas Jennis, it argues that migrant circles in and around Frankfurt functioned as transfer zones for literary cultures between Germany and other European countries. Frankfurt publishers were often part of transnational migrant networks and were especially important for the introduction and popularization of new forms of religious literature in early modern Germany.
\end{abstract}

In 1624, two years after Catholic League troops conquered Heidelberg and many Protestant inhabitants had left town, a modified German edition of Julius Wilhelm Zincgref’s

Emblemata Ethico-Politicorum Centuria, titled Sapientia picta, appeared in the Frankfurt publishing house of Peter Mareschall (Figure 1). ${ }^{1}$ Mareschall, who had left Heidelberg for Strasbourg after the siege and was later praised as a steadfast Christian who had chosen exile for the sake of religion, dedicated the emblem book to his brother-in-law, Daniel Bélier. Both men had a migrant past, even before the fall of Heidelberg: Mareschall descended from a Lyon family, and Bélier's parents were from Tournay; both families had fled religious persecution and military devastation in their homelands.

In his dedication, Mareschall presents Classical and Biblical commonplaces regarding the true home of man in general and of the Christian in particular. Departing from Socrates, who regarded Athens as his hometown, but the whole world as his homeland, Mareschall moves to Ovid's reflections on exile and his assertion that "a brave and able man could be at home in any country."2 Mareschall then proceeds with the image of the Christian pilgrim, who is always journeying toward his true home: Christians should not seek permanent homes 
in the world, but should trust God to guide them along the journey to their true and eternal home. However, he notes the importance of having close friends, even if they live far away. While this life is an endless pilgrimage, Mareschall writes, friendship helps people find their way.

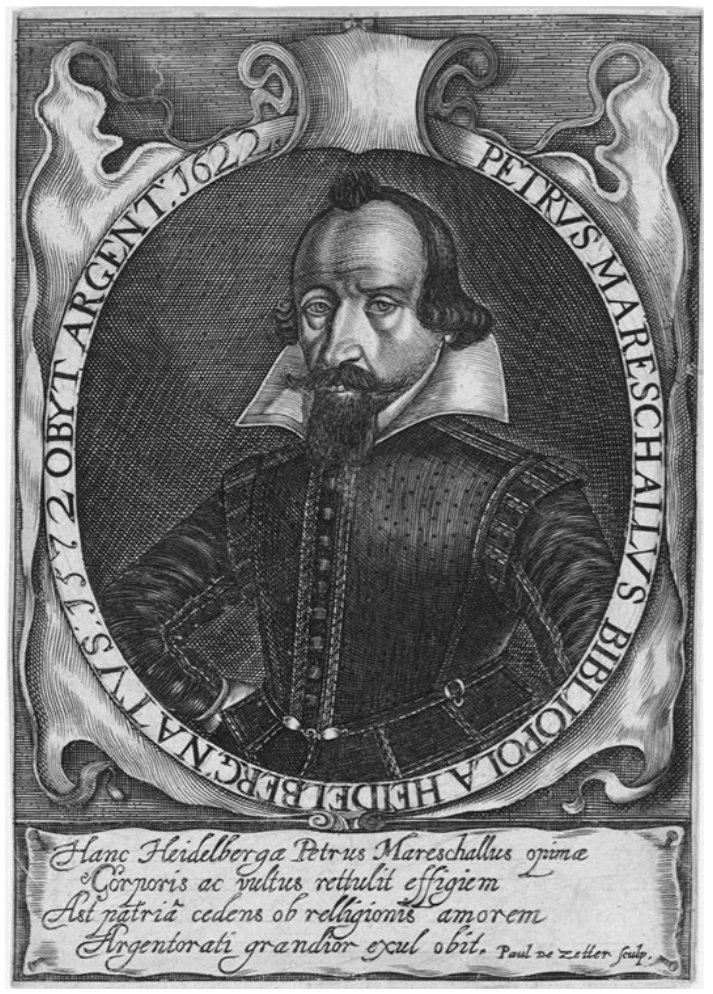

Figure 1.

Paul de Zetter, Peter Marschall (sic), "This image brings back the likeness and countenance of Peter Mareschall from fertile Heidelberg. He left his home for religion's sake and died-nobler-as an exile in Strasbourg." Rijksmuseum Amsterdam (Public domain). Copyright information: https://www.rijksmuseum.nl/en/photoservice

Though Mareschall's dedication contains the typical conventions and commonplaces of affectionate seventeenth-century book dedications, it reveals two important aspects of the lives of migrants like Bélier and Mareschall. Like many early modern Europeans, they were forced to move several times during their lives. Thus they lived between various cultural, religious, and political environments. Though they belonged to the urban elites in their new homes - Bélier's father was a burgomaster of Heidelberg, an unusual position for someone without ancestral connections in the city - they were also connected to distant people and places. ${ }^{3}$ In this situation, maintaining long-distance friendships was a necessity: friends, family members, and business partners in other regions provided economic opportunities that 
were crucial for early modern merchants and artists, as well as for printers, publishers, and booksellers with migrant backgrounds.

The cultural and geographical outlook of such entrepreneurs was broad: they were intermediaries between many worlds and lived highly mobile lives, both in cultural and geographical terms. To illuminate how these intermediaries shaped the seventeenth-century German literature market, this article examines the migrant publishing network around Christoph (or Christoffel) Le Blon, a prolific publisher of religious literature, and his contacts Joachim von Sandrart, Friedrich Hulsius and Lucas Jennis, all of whom were descendants of related southern Netherlandish migrant families in Frankfurt. It shows how their "multiple rootedness" between different cultural and geographical contexts shaped their publishing activities and their contributions to seventeenth-century German literature-especially religious literary traditions. It also argues that migrant circles in Frankfurt facilitated the transfer of German and European cultural traditions and innovations and that publishers with diasporic roots acted as intermediaries in transnational networks of migrant authors. This cultural transfer included not only works and traditions from the publishers' regions of origin but also those from other countries.

Considering the large number of texts created by exiles and migrants in early modern German-speaking Europe, it is surprising that German migrant literature in the centuries between the Reformation and the Enlightenment has received little notice in modern scholarship. ${ }^{4}$ Therefore this article also aims to bring attention to migration and exile as an often-neglected cultural-historical context of early modern German literature and its production. Addressing the impact of mobility and migration on early modern literature and book culture allows a better understanding of how new cultural and religious identities in Germany were shaped and how the transnational connections of migrant writers and 
publishers facilitated cultural and literary transfer between German and other European regions.

While the constant influx of migrants shaped the urban centers of the Holy Roman Empire long before the Reformation, confessional antagonism intensified transregional migration and its impact on urban cultures. Mass persecutions of Protestants in the Low Countries and the outbreak of religious violence in France brought large groups of exiles into sixteenth-century Germany. Among them were writers, publishers, and printers, who not only translated their works into German, but also wrote and published in the language of their new host society. ${ }^{5}$ For example, Theatrum, das ist Schauplatz, by Jan van der Noot, a Cologne exile from Brecht in Brabant, was translated from the original Dutch; however, Van der Noot wrote his Das Buch Extasis in German. ${ }^{6}$

Many of these exiles headed for Frankfurt. Even though the Lutheran town was not always a particularly friendly environment for Reformed migrants, who composed a majority of the French and Netherlandish refugees, its economic opportunities continued to attract refugees from Flanders, Brabant, and Wallonia. ${ }^{7}$ When Frankfurt banned Reformed church services in 1561, many Calvinists went to Frankenthal and Oppenheim, but they often returned later. As the most important center for the German book trade, Frankfurt remained a logical choice for refugee writers and publishers.

With the outbreak of the Thirty Years' War, internal migration within the empire quickly increased, and many authors were forced to leave their homes to save their lives, practice their religion, or secure their social and economic positions in a poor and violenceridden surrounding. While some, such as Andreas Gryphius, were able to return to their hometowns, others, such as Catharina von Greiffenberg, Anna Ovena Hoyer, and Wolf Helmhardt von Hohberg, stayed in exile for the rest of their lives. ${ }^{8}$ In the aftermath of the Lutheran and Utraquist migrations from Bohemia and Silesia, a flood of consolatory tracts, 
poems, and printed sermons on exile were published. ${ }^{9}$ New migration waves followed the 1685 revocation of the Edict of Nantes, which had protected Huguenots in France, the Nine Years' War (1688-1697), and the 1731 expulsion of Lutherans from Salzburg. The exodus of both Huguenots and Salzburgers left remaining traces in German and European collective memory and created a popular culture that commemorated refugees' exile with songs like Johann Schaitberger's Ich bin ein armer Exulant, which is still sung in Austrian Lutheran churches today. ${ }^{10}$

Among these refugees were individuals of all religious confessions, but also migrants who rejected all forms of confessionalism. However, in the wake of Heiko Oberman's work on the Calvinist "Reformation of the refugees," church and migration historians have long focused on Calvinist exiles in the Holy Roman Empire. ${ }^{11}$ In reaction, some scholars have recently focused on refugees of other confessions, such as Catholics, Lutherans, or Mennonites, while other scholars have argued that confessionalism did not necessarily play an important role in early modern exile networks. ${ }^{12}$ Comparisons between the cultivation of migrant identities in different confessional camps show that Calvinists were not significantly more active in disseminating their exile identities in religious terms and that the imagery used by believers of different confessions was often very similar to that of Calvinists. ${ }^{13}$

Most of those refugees and exiles did not migrate to just one place; instead, they continued to move on to new towns and regions — often because of the military devastations of the Thirty Years' War, as was the case for Peter Mareschall. In contemporary migration studies such behavior is described as "transmigration," contrary to older scholarship, which often thought of human migration as "a unilinear, stage-like process of incorporation or assimilation" and overlooked migrants' individual practices and allegiances to diverse social and cultural entities. ${ }^{14}$ The notion of migration as a unidirectional movement with clearly defined points of departure and arrival or cultural difference and assimilation does not 
sufficiently describe the complex processes of modern and early modern migration movements. As many contemporary examples demonstrate, instead of moving from one nation-state to another and leaving all ties behind, migrants often stay engaged in processes that bridge and transcend the boundaries between stops along their journey. Scholars such as Nina Glick Schiller and others have therefore argued that contemporary migrants should be characterized not as "uprooted" but rather as "becoming firmly rooted in their new country, but maintaining multiple linkages to their homeland" or, as Michael Peter Smith has described it, being at home "both here and there." 15

As in many present-day migration movements, unidirectional migration was not the norm for early modern exiles, especially not for merchants, artists, artisans, publishers, booksellers, and clerics: for migrants from the Low Countries, moving back and forth between Holland and places like Frankenthal, Frankfurt, Oppenheim, and Nuremberg was the rule rather than the exception. ${ }^{16}$ As agents of cultural transfer, with networks in both their old and new homes, such migrants built connections between European regions. The four publishers presented here were second-generation migrants, but even though they were firmly rooted in their new places of residence, they stayed connected to transregional migrant networks.

The literary transfer of these Frankfurt migrant publishers produced what I call a "transmigrant literature." This term does not denote a stable literary category, but instead refers to (a) the social and cultural contexts of literary texts written and published within translocal networks, (b) the transmigration of the texts themselves, which were sometimes published simultaneously in different European countries by migrants' transnational publishing houses and traveled back and forth between different cultural, religious, and linguistic settings, and (c) the dissemination of "transmigratory" identities, in which migration 
was redefined in terms of Christian pilgrimage, or as Peter Mareschall described, being at "home in all the world."

One of the migrant publishers in Christoph Le Blon's network and a typical example of an early modern transmigrant was Joachim van Sandrart, artist, publisher, and author of the Teutsche Academie der Edlen Bau-, Bild- und Mahlerey-Künste and many other art-historical works. Von Sandrart was born in Frankfurt to Walloon parents in 1606 and stayed connected to his Frankfurt network throughout his life. Between 1637 and 1642 he worked in Amsterdam, after living in Nuremberg and Utrecht. As his anonymous biographer stated, his relocation to Holland was due to the threatening military situation in Frankfurt during the mid-1630s. ${ }^{17}$ From Holland he moved to the Palatinate and then to Nuremberg, where many exiles from the Low Countries had migrated in the late sixteenth century. ${ }^{18}$

However, neither Von Sandrart nor the other individuals discussed here can be described as "footloose," as Oscar Gelderblom recently characterized the class of internationally oriented merchants and entrepreneurs in early modern Europe. ${ }^{19}$ Von Sandrart quickly integrated into the cultural life of each new town. In Nuremberg, where his productivity reached its peak, he was admitted to the prestigious Fruchtbringende Gesellschaft and had friends among the members of the Pegnesische Blumenorden, especially Sigmund von Birken, a son of Lutheran exiles from Bohemia, with whom he collaborated in the publication of the Teutsche Academie. In Amsterdam he established contacts with Joost van den Vondel, Pieter Corneliszoon Hooft, Samuel Coster, Gerard Vossius, and other famous Dutch writers. Von Sandrart made portraits of these men and produced illustrations for their books. He also created twelve paintings of the months of the year for Elector Maximilian I of Bavaria and relied on his Amsterdam network for this project. Vondel and Caspar Barlaeus, both of whom had southern Netherlandish exile backgrounds, wrote accompanying poems in Dutch and Latin (see Figure 2 for Vondel's poems), which Von 
Birken translated into German. ${ }^{20}$ Thus, rather than being footloose, individuals like Von

Sandrart were firmly rooted in multiple settings and environments.

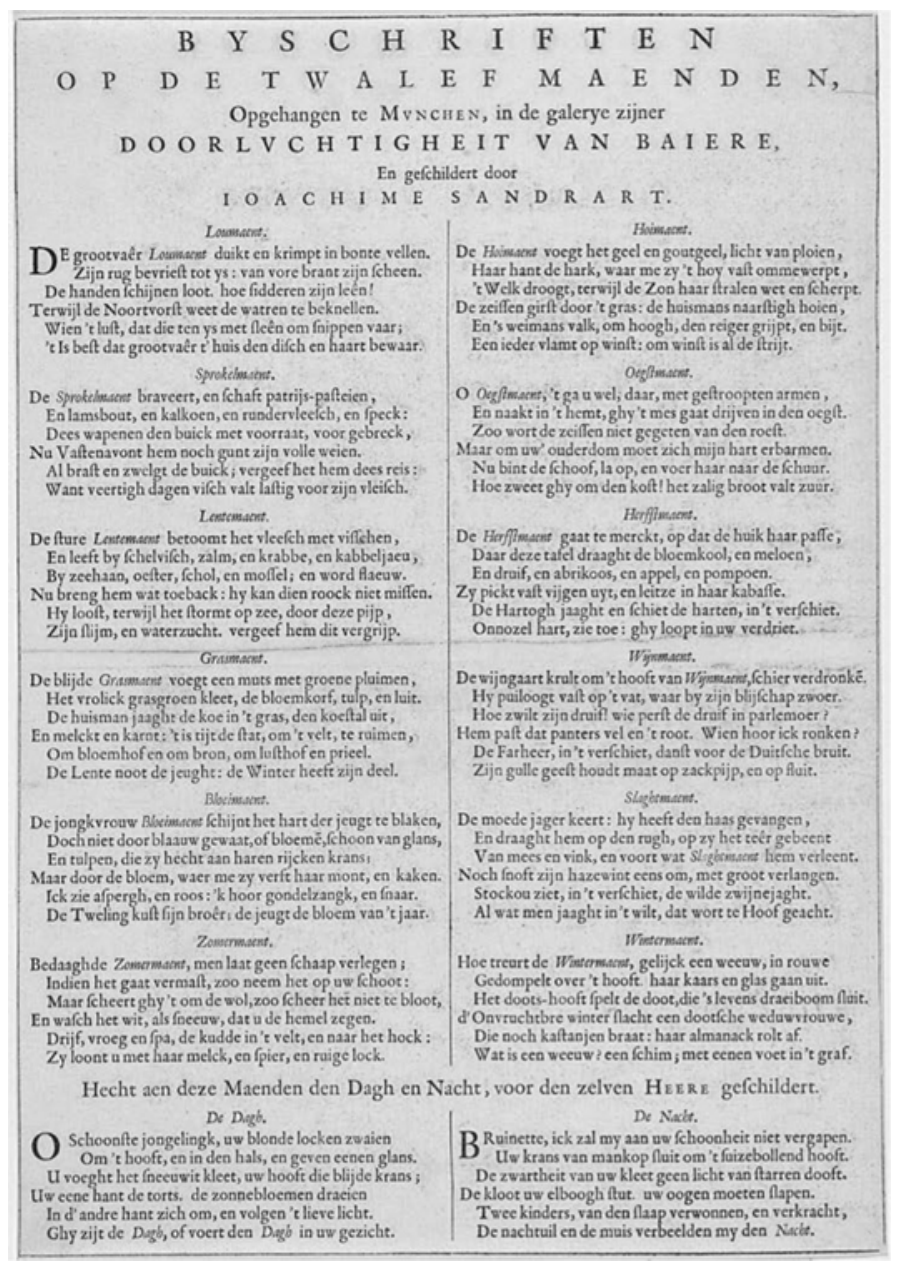

Figure 2.

Joost van den Vondel, Byschriften op de twalef maenden. Opgehangen te Mvnchen, in de galerye zijner Doorlvchtigheit Van Baiere, En geschildert door Ioachime Sandrart,

Rijksmuseum Amsterdam (Public domain). Copyright information: https://www.rijksmuseum.nl/en/photoservice

Von Sandrart's artistic and publishing activities connected Dutch and German literary networks and combined cultural traditions from both language areas. For example, in 1679 he translated Karel van Mander's Dutch paraphrase of Ovid's Metamorphoses into German. Van Mander, also a southern Netherlandish exile, played a significant role in Von Sandrart's publishing activities. The Teutsche Academie, the first encyclopedic history of art written in German, which contained the first biographies of many German artists, was heavily influenced by and modeled after Van Mander's biographical-historical Schilder-Boeck and even borrowed many passages from the Dutch-Flemish poet and artist. Even though Von Sandrart also used Italian art-historical works as models, Van Mander's Dutch work laid the 
foundation of the Teutsche Academie and of German-language literature on the history and theory of the visual arts.

Migrant publishers who were less itinerant than Von Sandrart also lived "transborder lives" and relied on contacts from past homes and other migrant towns for their business. ${ }^{21}$ Von Sandrart's cousin, Christoph Le Blon, probably never left Frankfurt for long periods. However, the activities of his publishing house were characterized by a broad geographical outlook and relied on his international network. Born to Walloon parents who fled their hometown, Valenciennes, in the late 1570s, the Low Countries played an important role throughout Le Blon's career. Christoph's brother Michel Le Blon moved to Amsterdam as a young adult and helped him maintain close ties between Frankfurt and Holland. Michel provided his Frankfurt family with texts to translate and publish and established contacts with German publishers and emigrated authors, such as the Wetzlar-born Hans Fabel and the brothers George and Samuel Hartlib. In Holland, where he worked for the king of Sweden, Michel befriended Joost van den Vondel, who wrote poems for Le Blon's sixty-fifth birthday. ${ }^{22}$ Michel probably also acted as an intermediary between the aforementioned Dutch poets and Von Sandrart. It is interesting that he became a member of the Brabant migrant rhetoricians chamber ' $t$ Wit Lavendel rather than the native Holland chamber-apparently second-generation refugees still identified with the southern Netherlandish diaspora, regardless of whether they had grown up in Germany or Amsterdam.

Christoph Le Blon was the son-in-law of the famous publisher Matthäus Merian the Elder, who was known for publishing topographical works and who had a wide range of religious works in his catalogue. Before Merian's death in 1650, Le Blon's catalogue included numerous French and Dutch works, some of which he translated into German himself. Among the authors he published were Anthoine Du Perier, Pierre de Cazeneuve, and Abraham Ravaud, and his catalogue included translated foreign novels, especially of the pastoral genre. 
He also published topographies of France and travel accounts, such as Willem Ysbrand Bontekoe's journal of his voyage to the East Indies. ${ }^{23}$ However, his focus changed after Merian's death. When Merian's heirs lost interest in publishing religious writings, Le Blon began publishing more spiritualist and mystical literature to fill this niche. Besides works of Johann Staupitz and Pseudo-Tauleriana, he published controversial material, for example Schwenckfeldian texts and works with antitrinitarian leanings. ${ }^{24}$

Though Le Blon primarily published for a German audience, he also made German texts he appreciated available to non-German speakers; for example, his interest in Jacob Böhme resulted in a French translation of De Signa Rerum by Jean Maclé. ${ }^{25}$ For the acquisition of sources, Le Blon relied on Michel, who had received several Böhme manuscripts from the Silesian mystic Abraham von Franckenberg. ${ }^{26}$ Le Blon's publishing also benefitted from an international network that provided him with new texts. In Frankfurt, he often collaborated with the second-generation Huguenot printer Johann Aubry. As a "cultural broker" between German-, French-, and Dutch-speaking Europe, Le Blon was active in multiple directions: he translated foreign-language literature into German and sometimes published German texts into French. ${ }^{27}$

Some of the books Le Blon published employed imagery of exile and exodus in an allegorized and strongly spiritualized form. He was involved in the 1651 publication of Richard Brathwaite's The Penitent Pilgrim and published Johann Arndt's sermons on the ten Egyptian plagues, signs for believers to leave Egypt for the promised land, as well as the anonymous Geistliche Schöpffung und Reise des wahren Israels aus Egypten (Spiritual creation and the journey of the true Israel out of Egypt). ${ }^{28}$ In the preface to Geistliche Schöpffung, Le Blon claimed it was based on a Dutch manuscript of unknown authorship and origin, which he had received from his brother. While some passages show similarities to the works of Dirck Volckertszoon Coornhert, especially the chapter on Abraham's exodus from 
Ur, there is no evidence for the existence of such a manuscript or another printed edition of the text. ${ }^{29}$ It is therefore possible that Le Blon not only translated the text but also rewrote passages.

Geistliche Schöpffung narrates Biblical history as an allegory for the internal spiritual development of the Christian believer. From the history of the creation and the fall of mankind to the life of the patriarchs, the exile motif is strongly pronounced throughout the entire book. The life of a Christian is presented as a pilgrimage "of the true Israel out of Egypt." From Abraham, who has to leave behind his hometown, Ur, in Chaldea, to Moses, Aaron, and Joshua, who have to lead Israel through the desert toward the Promised Land, the heroes of the Old Testament represent spiritual role models who exemplify obedience to God and work to gather the true believers. Geistliche Schöpffung sharply distinguishes between typological Egypt and the true Israel, which signify two antagonistic spiritual principles, the bondage to the world and the orientation toward godly things, respectively:

While the land of Egypt signifies this world, it is very common that man begins to love this earthly time beyond any measure, when he lives in joy and happiness to which he is so attached that he does not desire eternity and so dazzled that he longs for nothing but temporal goods in Egypt all of his days.... ${ }^{30}$

To spur the Christian to leave Egypt and move on to the Promised Land, God often has to use afflictions to convince believers of the vanity of all worldly things. Even the elect often remain obstinate and need to be brought to redemption:

Man is not earlier released from this world, if he is not aggrieved before. Yea, before he is released from the Egypt of this world, he must carry away the great penances and 
the filth, for he must learn to withstand all evil and wicked deeds that are opposed to nature and in which man is tried, before he can leave the Egypt of this world. ${ }^{31}$

Such theological interpretations of the exodus narrative, which aimed to guide and reflect the spiritual development of individual believers, had been used by exiled writers since the persecutions following the early Reformation. Abraham, Moses, and even Jesus himself were presented as exemplary exiles and role models for persecuted Christians in the present. ${ }^{32}$ The idea of a separation of the true Israel from unholy Egypt was also interpreted in an ecclesiological sense. In the nonconformist circles around Le Blon, who always remained a member of the Frankfurt Reformed church, moving out of Egypt meant leaving the community of what they regarded as lukewarm Christians in the institutional churches to search for more purity or spiritual enlightenment. Spiritual conventicles outside the churches aspired to be gatherings of the true Israel that had to leave "Babylon," and as such, they played an essential part in the culture of Pietism in Frankfurt that emerged in the 1670s. ${ }^{33}$ While Philipp Jacob Spener, the influential initiator of the so-called collegia pietatis, did not envisage these conventicles as entities separate from the church, but as gatherings of the ecclesiola in ecclesia, or the small community of saints within the larger (institutional) church, separatist tendencies strongly influenced the culture of Pietist conventicles and informal spiritual circles. The works published by Le Blon found avid readers in these milieus. $^{34}$

As a cultural broker between different religious and cultural traditions, Le Blon was also at the center of a loose network of religious authors throughout northern and western Germany and the Low Countries. Many of these authors lived itinerant lives-for example, the Flemish kabbalist and alchemist Franciscus Mercurius van Helmont, the German spiritualist Christian Hoburg, and the Scottish Reformed minister John Dury, who was also a 
member of the Hartlib circle. Despite his focus on the German market, Le Blon had a decidedly international outlook as a publisher and worked in close cooperation with Heinrich Betkius, a German publisher from Lübeck who was active in Amsterdam. ${ }^{35}$ Between 1659 and Le Blon's death in 1665 , they cooperatively published twenty-one to thirty books in both Frankfurt and Amsterdam. ${ }^{36}$ Among their most successful projects was their publication of Christian Hoburg's spiritual emblem books. Since the late sixteenth century, networks of Dutch migrants had been critical to the evolution of spiritualist-mystical emblem literature published in German, and many of the first publishers of such books had a southern Netherlandish exile background, for example Hieronymus Commelinus in Heidelberg, who published French works in this genre, Lucas Jennis in Frankfurt, and later Le Blon. ${ }^{37}$

Hoburg, a Lutheran minister from Lüneburg, had become increasingly attracted to mystical spiritualism and the works of controversial sixteenth-century authors like Caspar Schwenckfeld and David Joris. When his spiritualist inclinations led to a break with Lutheran orthodoxy, he moved to the Netherlands and became a Reformed minister in Zutphen. Due to his nonconformist views, however, he was soon dismissed. Hoburg then moved to Amsterdam, where he stayed for a time with the French mystic Antoinette Bourignon, author of La lumière nee en tenebres, parts of which he translated into German. ${ }^{38}$ In Amsterdam he began work on the mystical emblem books Emblemata Sacra and Lebendige Hertzenstheologie, which were published by Le Blon and Betkius. ${ }^{39}$ The latter title contained twentytwo emblems from the French emblem book, Le Coeur devot, by the Jesuit author Etienne Luzvic, accompanied by new poems by Hoburg. ${ }^{40}$

In the spiritualist and proto-Pietist networks, such transconfessional incorporations were not uncommon, and even though the religious nonconformist networks between the Netherlands and Germany were never entirely deconfessionalized, the distinction between "true Christians" and "children of the world" was not necessarily a distinction in confessional 
terms. Hoburg seems to have switched between various confessional settings easily — when he left Amsterdam in the last year of his life, he went to Altona and became a minister to the Dutch Mennonite congregation there. With itinerant individuals like Hoburg, ideas, texts, and images traveled across not only geographical and cultural borders but also religious boundaries, and migrant publishers like Le Blon and Betkius played a significant role in these transfer processes.

Another traveling author in Le Blon's migrant network was John Dury. As the son of an exiled Presbyterian minister from Edinburgh, he grew up in Leiden and later became a minister in Elbing (northern Germany), where a substantial Dutch-speaking Reformed exile community had been present since the mid-sixteenth century. During the English Civil War he traveled between England, Holland, and Germany, establishing contacts with the exile network of Johann Amos Comenius, as well as with a number of mystical spiritualists in the Low Countries. In his later years Dury was active in Kassel, though he stayed connected to his older transnational networks. ${ }^{41}$ It is therefore not surprising that Le Blon was not Dury's only publisher with an exile background; his works were published by other actors in transnational migrant networks, such as the southern Netherlandish Villiers family in Bremen. $^{42}$

Frankfurt's migrant networks around Le Blon functioned as important transfer channels that provided German speakers with Puritan works from England, which played a significant role in Frankfurt's nonconformist and proto-Pietist circles. One member of these networks was the publisher Friedrich Hulsius (or van Hulsen), who specialized in the publication of English Puritan literature and whose publishing activities were continued by Le Blon in the late 1630s. Friedrich was the son of Levinus Hulsius, a Flemish publisher of astronomical, geometrical, and mathematical books and maker of scientific instruments. 
Levinus and his wife, Maria Ruting, had migrated from Ghent, to Middelburg, Nuremberg, Oppenheim, and finally Frankfurt, building a network of contacts along the way. They also had a network in England, probably resulting from contacts with other southern Netherlandish migrants in London. Around 1602 Levinus Hulsius stayed in England for at least a few months. ${ }^{43}$ His son Bartholomeus, who had studied theology in Leiden, later became a minister at Austin Friars, the Dutch Reformed Stranger Church in London. After Levinus's death, his widow increased the publishing house's focus on English devotional literature in German translation. When their son Friedrich took over the publishing house, he expanded this catalogue. By the time of his death, works by William Perkins, Arthur Dent, Robert Abbot, and other Puritan writers dominated his catalogue. ${ }^{44}$

These works were immensely popular among early Frankfurt Pietists and in the preceding religious circles that influenced them. ${ }^{45}$ The Puritan distinction between true believers and indifferent lukewarm Christians is thought to have greatly influenced Pietist exclusivism in Germany. Udo Sträter and others have correctly argued that the Puritan influence on German Pietism should be put into perspective: English devotional literature was also popular outside Pietist circles, and many Pietist ideas had their roots in older Lutheran devotional traditions. ${ }^{46}$ However, Jan van de Kamp convincingly argues that Pietist exclusivism and the reevaluation of Christian discipline in everyday life can be ascribed to Puritan influences, especially to Perkins, whose works formed the backbone of Hulsius's catalogue. ${ }^{47}$ When Le Blon acquired Hulsius's publishing house, he kept many of these English titles in his catalogue, though to a lesser extent than his predecessor.

Another member of Frankfurt's migrant circles was the publisher Lucas Jennis, who was related to Le Blon and Von Sandrart by marriage. Jennis had specialized in alchemistic and hermetic literature but also published many emblem books and translations of French and Italian novels as well as historical and art-theoretical works. ${ }^{48} \mathrm{He}$ also published several texts 
of the medieval Dutch mystic Jan van Ruusbroec, sometimes put out under the name of the better-known Johannes Tauler. ${ }^{49}$ After Jennis's death in the the early 1630's, Christoph Le Blon reiussed many of his titles. These works were the foundation of Le Blon's early catalogue, though the alchemistic titles became less important later on. ${ }^{50}$ Many of the authors Jennis published belonged to his personal network, especially authors of alchemistic literature, and he had one of the richest catalogues of alchemistic prose and poetry in early modern Germany. Like his father from Brussels, Jennis was also active as an engraver, a craft he had learned from the famous Theodore de Bry, and he illustrated many of his own works. ${ }^{51}$ Through Michel Le Blon, Jennis's works also found their way to Amsterdam. His devotional tract Krämer-Korb, mit sieben beschlossenen Laden was published there by Hans Fabel. ${ }^{52}$

With his Dutch connections, Jennis was able to expand into the Dutch book market, as Bert Both and Els Stronks have demonstrated.$^{53}$ One of his contacts was the aforementioned Bartholomeus Hulsius, who served as minister to the Dutch Reformed congregation in London before resettling to Cillaarshoek, a small village between Rotterdam and Dordrecht. In 1631 Hulsius's religious emblem book Emblemata sacra appeared in Jennis's publishing house. ${ }^{54}$ The images were taken from Zincgref's Emblemata Ethico-Politicorum Centuria, mentioned at the beginning of this article, which was published by various migrant publishers in Frankfurt and Heidelberg. The Frankfurt-born Bartholomeus Hulsius, who was familiar with Zincgref's book, reinterpreted the political emblems, giving them new spiritual meanings. In the preface to his work, Bartholomeus addressed the Austin Friars congregation in London to whom he dedicated the work. As one of the first Reformed religious emblem books in Dutch, the Emblemata sacra reflected the translocal and transnational orientation of the seventeenth-century Netherlandish diaspora: it was written in Dutch, dedicated to an audience in England, and printed in Frankfurt. 
The four publishers examined here — Le Blon, Von Sandrart, Hulsius, and Jenniscontributed to early modern Frankfurt's and Germany's book culture by providing access to books that were difficult to acquire without contacts throughout Europe, books that were formative for new religious and literary cultures in Germany. Von Sandrart was one of the initiators of art-historical and art-theoretical writing in German, Le Blon and Hulsius were particularly instrumental in the transfer of devotional literature from England and the Low Countries, and Jennis was one of the major suppliers of alchemistic and Rosicrucian works as well as religious emblem literature.

While Frankfurt, with its connections to other towns and regions, was the most important German city for the early modern book trade, individuals with migrant roots could establish connections much more easily and effectively than could those without migrant roots. Most migrants had family connections in their old hometowns or other migrant cities, and they were able to establish new contacts as they moved from one place to another. As the introductory example of Peter Mareschall and Samuel Belier illustrated, migrants and their descendants tried to confirm and maintain these distant contacts. ${ }^{55}$ Christoph Le Blon had access to Dutch texts from Amsterdam and Böhme manuscripts through his brother Michel. As he himself asserted, his brother's connections played a decisive role in the acquisition of publishable texts. Given that the German book market was becoming increasingly "nationalized" during this period, with fewer foreign books coming into the yearly Frankfurt book fair, the value of such connections should not be underestimated. ${ }^{56}$

The language skills of migrants and their children were also a great advantage for the publishing business. Indeed, when German publishers looked for translators, they often hired migrants. ${ }^{57}$ The four publishers highlighted here translated Dutch, English, French, Latin, and probably also Italian books into German, although Von Sandrart was assisted by Sigmund von Birken in writing the Teutsche Academie. Le Blon even published Böhme in French 
translation. In this respect the four cases are not exceptions: other migrant or secondgeneration migrant publishers who published and popularized great numbers of translated works show the same pattern, including Johann Aubry, André Wechel, Jacob de Zetter, Philipp and Daniel Fievet in Frankfurt; Thomas and Berthold de Villiers in Bremen; Adriaan Wyngaerden and Samuel Browne in Heidelberg; and Thomas von Wiering in Hamburg. ${ }^{58}$

Peter Burke has identified early modern migrants as important translators and cultural brokers between cultures and traditions. As "Renaissance go-betweens," translators used their intercultural skills to "make a career out of their displacement." 59 The migrant publishers presented in this article fit into Burke's category, yet it is important to note that they all belonged to the second generation of migrants. As children of migrants they neither left their parents' past behind nor were they isolated in exclusive migrant communities. More so than the first generation, they were able to act on local and translocal levels, and with the exception of Friedrich Hulsius, whose father had already translated numerous Dutch works into German and was famous for the publication of his French-German dictionaries, they were more active as cultural mediators than were the publishers of their parents' generation. ${ }^{60}$ At home both in Frankfurt and in the diaspora networks of their parents, they were go-betweens even more so than the first migrant generation.

Second-generation migrant publishers in Frankfurt, especially Christoph Le Blon, were active in circles where transmigration and itineration was common. Many actors in Le Blon's networks, such as Franciscus van Helmont, Christian Hoburg, Heinrich Betkius, and John Dury, were constant travelers between Dutch-, German- and English-speaking worlds. Michel Le Blon's network, which his son continued after his death in 1658, showed the same characteristics: Hans Fabel, Abraham von Franckenberg, as well as the Hartlib brothers, led itinerant lives between Amsterdam, London, and Germany. German nonconformists abroad 
used the established networks of second-generation migrants in Germany and their connections to Amsterdam and other cities.

This milieu, in which new religious ideas and texts were circulating, fashioned transnational identities and the notion of Christian pilgrimage through the world, as expressed by Peter Mareschall in his Sapientia Picta dedication. In a spiritual tract, George Hartlib proudly called himself an "exul," and in the works published by Hans Fabel, exile and wandering are often interpreted in an allegorized spiritual form similar to Le Blon's Geistliche Schöpffung. ${ }^{61}$ The mentality of these "homeless minds," as Douglas Shantz characterized early modern migratory dissenters, was strongly influenced by the imagery of pilgrimage and wandering. ${ }^{62 ~ " H o m e l e s s ~ m i n d s " ~ l i k e ~ H o b u r g, ~ B e t k i u s, ~ V a n ~ H e l m o n t, ~ a n d ~ F a b e l ~ s o u g h t ~ a ~}$ cultural and geographical infrastructure, and they found it in the migrant networks that dated back to the period of persecution and exile; these networks had different functions than for the first generation of refugees who needed to stay in touch with relatives, business partners and fellow migrants. These findings show that early modern cultural and literary transfer can be better understood through a diachronic and cross-generational approach. ${ }^{63}$ Understanding the publishing choices and strategies of people like Le Blon requires an examination of their second-generation migrant backgrounds and their family histories. Their upbringing in a culturally hybrid surrounding and their ties to other European regions enabled them to act as agents of exchange and as successful "cultural brokers."

\footnotetext{
${ }^{1}$ Anon. (Julius Zincgref) Sapientia Picta. Das ist/ Künstliche Sinnreiche Bildnussen vnd Figuren/darinnen denckwürdige Sprüch vnd nützliche Lehren im Politischen vnd gemeinen Wesen durch hundert schöne newe Kupferstück vorgebildet/ entworffen/vnd durch teutsche Reymen erkläret werden. So auch zu einem Stamm oder Wappen Büchlein füglich zugebrauchen (Frankfurt: Peter Mareschall, 1624). On the question of authorship of this work, see Curt Von Faber Du Faur, "The Author of the "Sapientia Picta"," The Yale University Library Gazette 28, no. 4 (April 1954): 156-160. The publications of Peter Mareschall, who died in Strasbourg in 1622, were continued by Johann Ammon who later published under his own name.
} 
2 Sapientia Picta, A2v.: "In gleichem meldet der fürtreffliche heidnische Poet Ovidius, und spricht: Daß ein jegliches Land eines dapffern starckmütigen Menschen Vaterland sey."

${ }^{3}$ These aspects have been studied extensively by Ole Peter Grell, who stressed the confessional character of such transnational networks and exchanges. See Ole Peter Grell, "The Creation of a Transnational, Calvinist Network and its Significance for Calvinist Identity and Interaction in Early Modern Europe," in European Revue of History 16, no. 5 (2009): 619-636; Ole Peter Grell, Brethren in Christ: A Calvinist Network in Reformation Europe (Cambridge: Cambridge University Press, 2011). On international Calvinist networks, see also Graeme Murdock, Calvinism on the Frontier, 1600-1660: International Calvinism and the Reformed Church in Hungary and Transylvania (Oxford: Clarendon Press, 2011).

${ }^{4} \mathrm{Among}$ the few scholars who have addressed this topic are Werner Wilhelm Schnabel and Alexander Schunka. See Alexander Schunka, "Constantia im Martyrium. Zur Exilliteratur des 17. Jahrhunderts zwischen Humanismus und Barock," in Frühneuzeitliche Konfessionskulturen, ed. Thomas Kaufmann, Anselm Schubert and Kaspar von Greyerz (Gütersloh: Gütersloher Verlagshaus, 2008), 175-200; Werner Wilhelm Schnabel: "Exulantenlieder. Über Konstituierung und Verfestigung von Selbst- und Fremdbildern mit literarischen Mitteln," in Frühneuzeitliche Stereotype. Zur Produktivität und Restriktivität sozialer Vorstellungsmuster. V. Jahrestagung der Internationalen Andreas Gryphius Gesellschaft Wrocław 8. bis 11. Oktober 2008, ed. Mirosława Czarnecka, Thomas Borgstedt et. al. (Jahrbuch für Internationale Germanistik, Reihe A Kongreßberichte 99, Berne: Peter Lang, 2010), 317-353; Werner Wilhelm Schnabel, Österreichische Exulanten in oberdeutschen Reichsstädten. Zur Migration von Führungsschichten im 17. Jahrhundert (Schriftenreihe zur bayerischen Landesgeschichte 101, Munich: C.H. Beck 1992). See also Jörg Witzel, "Amalia von Stubenberg, geb. von Liechtenstein (1593-1664). Adlige Glaubensflüchtlinge aus Österreich im Nürnberger Exil," Blätter der Gesellschaft für Buchkultur und Geschichte 16, no. 17 (2013): 96-99. Peter Burke has studied the role early modern migrants as translators. See Peter Burke, Lost (and Found) in Translation: A Cultural History of Translators and Translating in Early Modern Europe (Wassenaar: Koninklijke Bibliotheek, 2005), 11. ${ }^{5}$ Leonard W. Forster, Die Niederlande und die Anfänge der Barocklyrik in Deutschland. Mit Textbeispielen (Groningen: J.B. Wolters, 1967).

${ }^{6}$ C.A. Zaalberg, ed., The Olympia Epics of Jan van der Noot: A Facsimile Edition of Das Buch Extasis, Een Cort Begryp der XII. Boecken Olympiados and Abregé des douze livres Olympiades (Assen: Van Gorcum, 1956).

${ }^{7}$ On Frankfurt's confessional politics betwen 1555 and 1685, see Anton Schindling, "Wachstum und Wandel vom Konfessionellen Zeitalter bis zum Zeitalter Ludwigs XIV. Frankfurt am Main 1555-1685," in Frankfurt am Main. Die Geschichte der Stadt, ed. Frankfurter Historische Kommission (Sigmaringen: Jan Thorbecke, 1991), 205-260. On the role of Frankfurt for early modern refugee networks, see also Michelle Magdelaine, "Frankfurt am Main: Drehscheibe des Refuge," in Die Hugenotten, ed. Rudolf von Thadden and Michelle Magdelaine (Munich: Beck, 1985), 26-37.

${ }^{8}$ Urs Herzog, "Literatur in Isolation und Einsamkeit. Catharina von Greiffenberg und ihr literarischer Freundeskreis," Deutsche Vierteljahrsschrift für Literaturwissenschaft und Geistesgeschichte 45, no. 4 (1971): 515-546.

${ }^{9}$ Among migrants from these regions, exile memories were often recorded in funeral sermons. See Schunka, "Constantia im Martyrium".Such funeral sermons by Andreas Gensreff, Johann Mülberger, Lachmundt, Johann Woldhammer, Johann Heinrich Kühn, Leopold Stephan, Anton Reiser, Johann Christian Blech, Benjamin Lehmann, Daniel Klesch, Melchior Himmelreich, Johannes Kemmel and many others can be found in VD17database.

${ }^{10}$ On Schaitberger, see Gustav Reingrabner, Johann Schaitberger, Bergmann und Exul Christi, Vienna 2000.

${ }^{11}$ Heiko A. Oberman, "Europa afflicta: The Reformation of the Refugees," Archiv für Reformationsgeschichte 83 (1992), 91-111.

12 On Catholic exiles from the Low Countries, see Geert Janssen, The Dutch Revolt and Catholic Exile in Reformation Europe (Cambridge: Cambridge University Press, 2014). On Lutheran exiles and the cultivation of their migrant identities, see Schunka, "Constantia im Martyrium". On inter- and transconfessionalism among Dutch refugees, see e.g. Jesse Spohnholz, The Tactics of Toleration: A Refugee Community in the Age of Religious Wars (Newark: Delaware University Press 2010); Mirjam van Veen, “Dirck Volckertsz Coornhert: Exile and Religious Coexistence," in Exile and Religious Identity, ed. Jesse Spohnholz and Gary Waite (London: Pickering \& Chatto, 2014), 67-80; Johannes Müller, “Exile Memories and the Dutch Revolt: the Narrated Diaspora, 1550-1750, Leiden: Brill, 2016.

${ }^{13}$ Müller, "Exile Memories and the Dutch Revolt", 40-54. See Vera von der Osten-Sacken, "Exul Christi: Konfessionsmigration und ihre theologische Deutung im strengen Luthertum zwischen 1548 und 1618," in Europäische Geschichte Online (Mainz: Leibniz-Institut für Europäische Geschichte, 2013), http://iegego.eu/de/threads/europa-unterwegs/christliche-konfessionsmigration/lutherische- 
konfessionsmigration/vera-von-der-osten-sacken-exul-christi-konfessionsmigration-im-strengen-luthertumzwischen-1548-und-1618

${ }^{14}$ Robert C. Smith, "Transnational Localities: Community, Technology and the Politics of Membership within the Context of Mexico and U.S. Migration," in Transnationalism from Below, ed. Luis Elgardo Guarnizo and Michael Peter Smith (New Brunswick/NJ: Transaction Publishers, 1998), 197. See also Michael Peter Smith, Transnational Urbanism. Localizing Globalization (Malden/MA: Wiley-Blackwell, 2001), 3-5.

${ }^{15}$ Nina Glick Schiller, Linda Basch and Cristina Szanton Blanc, "From Immigrant to Transmigrant: Theorizing Transnational Migration," Anthropological Quarterly 68 (1995) 1, 48-63; Michael Peter Smith, "Translocality: A Critical Reflection" in Translocal Geographies: Spaces, Places, Connections, ed. Katherine Brickell and Ayona Datta (Farnham: Ashgate, 2011), 181. See also Michael Peter Smith, "The Two Faces of Transnational Citizenship," Ethnic and Racial Studies 30, no. 6 (2007): 1096-1116. While transnationalism of this kind is often thought of as a very recent phenomenon and is linked to theories about the "end of the nation state," Leo Lucassen has questioned the newness of such phenomena. As he argues, during the height of modern nationalism in the nineteenth and twentieth centuries, migrant communities were able to surpass national borders and ethnic differences, for example in the case of Catholics who formed transnational networks during the German Kulturkampf of the 1870s. (Leo Lucassen, "Is Transnationalism Compatible with Assimilation? Examples from Western Europe since 1850," IMIS-Beiträge 29 (2006): 11-31.)

${ }^{16}$ Müller, "Exile Memories and the Dutch Revolt," 159-166.

${ }^{17}$ Esther Meier, "Joachim von Sandrarts “LebensLauf". Dichtung oder Wahrheit?," Marburger Jahrbuch für Kunstwissenschaft, 31 (2004): 220.

${ }^{18}$ Christian, Klemm, "Sandrart, Joachim von" in Neue Deutsche Biographie, vol. 22 (2005), 425-427

(http://www.deutsche-biographie.de/ppn118794396.html). On Nuremberg as a center for Reformed refugees from France and the Netherlands, see Grell, Brethren in Christ, 140-163; Kurt Pilz, "Nürnberg und die Niederlande," Mitteilungen des Vereins für Geschichte der Stadt Nürnberg 43 (1952): 1-153.

${ }^{19}$ Oscar Gelderblom, Cities of Commerce: The Institutional Foundations of International Trade in the Low Countries. 1250-1650 (Princeton: Princeton University Press, 2013).

${ }^{20}$ Karel Porteman, ed., De Maanden van het jaar. Joachim von Sandrart, Joost van den Vondel, Caspar Barlaeus (Wommelgem: Den Gulden Engel, 1987).

${ }^{21}$ For the term "transborder lives," see Lynn Stephen, Transborder Lives: Indigenous Oaxacans in Mexico, California, and Oregon (Durham/NC: Duke University Press, 2007).

22 See Joost van den Vondel, "Jaergetyde van den heer Michiel le Blon, 1652: Margriet. Michiel," De werken van Vondel. Deel 5. 1645-1656, ed. J.F.M. Sterck et.al. (Amsterdam: Van Lennep, 1931). On Michel Le Blon, see also Badeloch Vera Noldus, "A Spider in its Web: Agent and Artist Michel Le Blon and his Northern European Network," in Double Agents: Cultural and Political Brokerage in Early Modern Europe, ed. Marika Keblusek and Badeloch Vera Noldus (Leiden: Brill, 2011), 161-192; Marika Keblusek, "The Business of News: Michel le Blon and the Transmission of Political Information to Sweden in the 1630s," Scandinavian Journal of History 28 (2003): 1-9.

${ }^{23}$ Though the exact numbers of Le Blon's publications are not clear, we know of at least forty-one titles published in Frankfurt and thirty titles published in collaboration with Heinrich Betkius in Amsterdam (See Karl Gustav Schwetschke, Codex nundinarius Germaniae literatae bisecularis. Meß-Jahrbücher des deutschen Buchhandels, 2 vols. [Halle: Schwetschke, 1850-1877], 95; 97; 99; 103; 106; 110; 127; 132). The VD17-database includes 35 titles published in Frankfurt, among which eleven religious works, six topographical titles, four translated novels as well as several medical and alchemistic works. For more titles published by Le Blon, for example the twenty-two English Puritan works in his 1641 catalogue, see Andreas Deppermann, Johann Jakob Schütz und die Anfänge des Pietismus (Tübingen: Mohr Siebeck, 2002), 25-26.

${ }^{24}$ Deppermann, Johann Jakob Schütz und die Anfänge des Pietismus, 25-26.

25 Jacob Böhme, Miroir Temporel De L'Eternite: Auquel est representé; Comment toutes choses sont marquées exterieurement selon leur forme interieure (Frankfurt: Le Blon, 1664).

${ }^{26}$ On Michel Le Blon and his Böhme-manuscripts, see also Leigh T.I Penman, "A Heterodox Publishing Enterprise of the Thirty Years' War: The Amsterdam Office of Hans Fabel (1616-after 1650)," Library 15, no. 1 (2014): 1-41.

27 Johanna von Bundschuh-Duikeren's bibliography of seventeenth-century Dutch books in German is incomplete in the presentation of Le Blon's, Friedrich Hulsius's and Lucas Jennis's work. The only mentioned works published by Le Blon are Christian Hoburg's Emblemata Sacra and Hendrick Brouwer's Schiffahrten. See Johanna Bundschuh-van Duikeren, Bibliographie der niederländischen Literatur in deutscher Übersetzung: Niederländische Literatur des 17. Jahrhunderts (Berlin: De Gruyter, 2011), 106; 519. Though it is not entirely clear how many of Le Blon's book he translated himself, he identifies himself as the translator of the 
anonymous Geistliche Schöpffung Und Reise deß wahren Israels auß Egypten/durch die Wüste in das gelobte Land: Darinnen Viele bißanhero unter Mosis-Decke gelegene Wörter und Namen der heiligen Schrift erkläret und zum geistlichen Zweck deß Christenthums erbaulich gefüget werden/Damit der Egyptische Welt-Mensch sich selbst erkenne/sterbe/ und zur Aufferstehung in Christo geführet werde/Dazu uns beydes das Alte und Neue Testament gegeben ist (Frankfurt: Le Blon, 1664).

${ }^{28}$ Richard Brathwaite, The penitent pilgrim: bemoning his sinfull condition. Faith appeares unto him affording him comfort hope seconds that comfort charity promiseth him in this vaile of missery to cover all his scarlett sins (London: Will. Sheares, 1651). Le Blon's exact role in this London publication is still unclear, but he is mentioned on the front page and was probably the engraver of the frontispiece. Johannes Arndt, Zehen schöne lehr- und geistreiche Predigten von den zehen grausammen und schrecklichen egiptischen Plagen (Frankfurt: Le Blon, 1657); Geistliche Schöpffung Und Reise deß wahren Israels auß Egypten.

${ }^{29}$ Geistliche Schöpffung, 17-18 (chapter 7, Von Abrahams Außganck, nach dem geistlichen gelobten Land, und seiner Berufung) and Dirck Volkertsz. Coornhert, "Abrahams Uytgangh," in Paul van der Meulen, ed., Het roerspel en de comedies van Coornhert (Leiden: Brill, 1955).

${ }^{30}$ Geistliche Schöpffung, 14 (my translation).

${ }^{31}$ Geistliche Schöpffung, 14.

${ }^{32}$ On Abraham as a spiritual role model, see e.g. Johannes Becius, Declaratio peregrinationis Abrahami (Arnhem, 1642); Melchior Himmelreich, Abrahami Patriarchae Honesta Peregrinatio \& Beata Emigratio (Breslau: Müller, 1620); Coornhert, "Abrahams Uytgangh". On Moses and the exodus narrative, see e.g. Ysbrand Balck, Het cleyn mostert-zaet, dat is, de laetste predicatie a. 1567. den 9 Aprilis, ende wederom, die naest-laetste predicatie den 18. Aug. a. 1585. binnen Antwerpen (Amsterdam: Adriaensz., 1590). On the motif of Jesus as an exile, see Johann Kemmel, Jesulus Exul, in Aegyptum fugiens, Das exulirende Kindlein Jesus/ wie Selbiges/für dem grausamen Wüterich Herodes/in Egyptenland entweichen und fliehen müssen: Allen Creutzträgern Christi zu Trost (Schleusingen: Göbel, 1684); Johann Christian Blech, Jesus Exul, Das ist/ Der aus seinem Vatterland vertriebene Jesus: In dem Jahr dieses Allerheiligsten Exulanten, 1690 (Oldenburg: Zimmer, 1690). Becius, Coornhert, Balck, Kemmel, and Blech had all experienced exile themselves, some even several times in their lives.

${ }^{33}$ Douglas Shantz, An Introduction to German Pietism (Baltimore: John Hopkins Press, 2014), 83; Deppermann, Johann Jakob Schütz, 183, 201.

${ }^{34}$ Though it is difficult to measure the exact impact of Le Blon's works within these circles, we know that leading Pietist separatists, such as Johann Jakob Schütz, read Le Blon's books and belonged to his circles (Deppermann, Johann Jakob Schütz, 347).

${ }^{35}$ Betkius's real name was Hendrick Beets, but he was such a devoted follower of the mystic spiritualist Joachim Betke that he adopted the surname Betkius. See Willem Heijting, "Christian Hoburg's "Lebendige Hertzens-Theologie (1661)": A Book in the Heart of Seventeenth-Century Spirituality" in Religious Minorities and Cultural Diversity in the Dutch Republic: Studies Presented to Piet Visser on the Occasion of his 65th Birthday, ed. August den Hollander, Alex Noord et al. (Leiden: Brill, 2014), 192-207 (204). See also Willem Heijting, "Hendrick Beets (1625?-1708): Publisher to the German Adherents of Jacob Böhme in Amsterdam" Quaerendo 3/4 (1973), 250-280.

${ }^{36}$ Deppermann, Johann Jakob Schütz, 26; Heijting, “Lebendige Hertzens-Theologie" 205. While Deppermann counts twenty-two titles, Schwetschke's Codex nundinarius includes thirty titles between 1659 and 1664 . (See Schwetschke, Codex nundinarius, 95- 99; 103; 106; 110; 127; 132).

${ }^{37}$ Commelinus published e.g.: Augustin Callias, Emblemata sacra e libris Mosis (Nuremberg, 1597). Among Lucas Jennis's publications were: Daniel Cramer, Emblemata Sacra, Das ist: Fünfftzig Geistliche in Kupffer gestochene Emblemata, oder Deutungsbilder/aus der Heiligen Schrifft/von dem süssen Namen und Creutz Jesu Christi (Frankfurt: Jennis, 1622); Andreas Friedrich, Emblemata Nova: das ist/ New Bilderbuch: Darinnen durch sonderliche Figuren der jetzigen Welt Lauff und Wesen verdeckter Weise abgemahlet (Frankfurt: Jennis, 1617). Jennis was also a prominent publisher of alchemistic emblem books such as: Hermetico-Spagyrisches Lustgärtlein: Darinnen Hundert und Sechtzig unterschiedliche/ schöne/ Kunstreiche/Chymico-Sophische Emblemata, oder Geheymnußreiche Sprüche der wahren Hermetischen Philosophen (Frankfurt: Jennis, 1625). ${ }^{38}$ Heijting, "Lebendige Hertzens-Theologie," 193-195.

${ }^{39}$ Christian Hoburg, Emblemata Sacra. Das ist/Göttliche Andachten/Voller Flammender Begierden einer Bußfertigen/geheiligten und liebreichen Seelen: In sehr artigen Bildern/mit zierlichen Kupfferstücken gantz lebendig auff NiederTeutsch vorgestellet (Amsterdam: Betkius/Le Blon, 1661); Christian Hoburg, Lebendige Hertzens-theologie/Das ist Andächtige Betrachtung/wie Jesus im Hertzen inwohne und würcke/ und im Hertzen der Liebhabenden sey alles mit schönen Bildern und artigen Kupfferstücken vor diesem vorgestellet (Amsterdam: Betkius/Le Blon, 1661). Another cooperative product of Le Blon and Betkius was Hoburg's Postilla 
Evangeliorum Mystica: Das ist/Verborgener Hertzenssafft aller Sontags und Fest-Evangelien durchs gantze Jahr (Amsterdam: Betkius/Le Blon, 1665).

${ }^{40}$ Heijting, "Lebendige Hertzens-Theologie", 199. On the adaption of the Catholic emblem tradition in

Protestant and nonconformist circles, see also Feike Dietz, Literaire levensaders. Internationale uitwisseling van woord, beeld en religie in de Republiek (Hilversum: Verloren, 2012).

${ }^{41}$ On the network of Dury, see Deppermann, Johann Jakob Schütz, 152; Kathrin Zickermann, Across the German Sea: Early Modern Scottish Connections with the Wider Elbe-Weser Region (Leiden: Brill, 2013), 189-202; Jan van de Kamp, "auff bitte und einrahten etzlicher frommen Menschen ins hochteutsche ubersetzet. Deutsche Übersetzungen englischer und niederländischer reformierter Erbauungsliteratur 1667-1697 und die Rolle von Netzwerken" (PhD diss., Free University of Amsterdam, 2011), 348. On Dury, see also Pierre-Olivier Léchot, Un christianisme "sans partialité." Irénisme et méthode chez John Dury (v. 1600-1680) (Paris: Honoré Champion, 2011).

${ }^{42}$ See e.g. John Dury, Informatio De lis, Quae In Studio Ecclesiasticae Concordiae, inter Evangelicos prosequendo agitare instituit Joannes Duraeus; erga Ecclesiarum Danicarum Theologos: oblata Illorum cognitioni, qui sua interesse putabant veras rerum in hoc negotio tractatarum circumstantias intelligere (Bremen: Villiers, 1639). John Dury, Informatio Ecclesiis Reformatis Oblata, De consiliis, quae agitata fuerunt in Pace Religiosa Cum ecclesiis Augustanis quaerenda (Bremen: Villiers, 1640).

${ }^{43}$ Manfred H. Grieb, ed., Nürnberger Künstlerlexikon. Bildende Künstler, Kunsthandwerker, Gelehrte, Sammler, Kulturschaffende und Mäzene vom 12. bis zur Mitte des 20. Jahrhunderts (Munich: K.G. Saur 2007), 711.

${ }^{44}$ Deppermann, Johann Jakob Schütz, 26.

${ }^{45}$ Van de Kamp, "auff bitte und einrahten etzlicher frommen Menschen," 34-36.

${ }^{46}$ See e.g. Udo Sträter, Sonthom, Bayly, Dyke und Hall. Studien zur Rezeption der englischen Erbauungsliteratur in Deutschland im 17. Jahrhundert (Tübingen: Mohr Siebeck 1987), 115.

${ }^{47}$ Van de Kamp, "auff bitte und einrahten etzlicher frommen Menschen," 357.

${ }^{48}$ Schwetschke lists 190 works published by Jennis. See Schwetschke, Codex nundinarius, 65; 67; 71-78; 80-85.

${ }^{49}$ Besides two chapters of Ruusbroec's Gheestelike Bruulocht, Jennis published Nachfolgung des armen Lebens Christi (Frankfurt: Jennis, 1621), which was ascribed to Tauler by Daniel Sudermann but was in fact a German translation of Ruusbroec's Vanden Blinckenden Steen. Several of these mystical texts were later reissued by other migrant publishers in Frankfurt, for example by Christoph Le Blon and Philipp Fievet.

${ }^{50}$ Deppermann, Johann Jakob Schütz, 25.

${ }^{51}$ Michiel van Groesen, The Representations of the Overseas World in the De Bry Collection of Voyages (15901634) (Leiden/Boston: Brill, 2008), 93.

52 Penman, “A Heterodox Publishing Enterprise," 16.

${ }^{53}$ Bert Both, Els Stronk, "Acceptatie van het vreemde - Pers- en geloofsvrijheid in de Republiek vanuit internationaal perspectief," Nederlandse Letterkunde 15, no. 2 (2010): 73-102, especially: 92.

${ }^{54}$ Bartholomeus Hulsius, Emblemata sacra, dat is, eenighe geestelicke sinnebeelden, met niewe ghedichten, schrifftuerlycke spreucken, ende bedenckinghen [s.I.], [s.n.]. While this edition does not mention a place of publication, Both and Stronks argue convincingly that Jennis was the publisher because the initials used in this edition are the same as in other emblem books from Jennis's business. (See Both, Stronk, "Acceptatie van het vreemde," 88).

${ }^{55}$ On efforts to maintain family ties in the southern Netherlandish diaspora between Holland and Central Europe, see also Luuc Kooijmans, Vriendschap en de kunst van het overleven in de zeventiende en achttiende eeuw (Amsterdam: Bert Bakker, 1997). On southern Netherlandish family networks, see also Johannes Müller, "Permeable Memories: Family History and the Diaspora of Southern Netherlandish Exiles in the Seventeenth Century," in Memory before Modernity: Practices of Memory in Early Modern Europe, ed. Erika Kuijpers, Judith Pollmann, Johannes Müller et al. (Leiden: Brill, 2013), 283-295.

${ }^{56}$ Reinhard Wittmann, Geschichte des deutschen Buchhandels (Munich: C.H. Beck, 1999), 84.

57 See e.g. Van de Kamp, "auff bitte und einrahten etzlicher frommen Menschen," 42; 342.

${ }^{58}$ On Aubry, see Josef Benzing, "Aubry, Johann" in Neue Deutsche Biographie, vol. 1 (1953), S. 427. On Wechel and his contacts within the international Protestant diaspora, see e.g. Alan Stewart, Philip Sidney: A Double Life (London: Pimlico, 2000), 78-80; 96-100; Robert Evans, The Wechel Presses: Humanism and Calvinism in Central Europe, 1572-1627 (Oxford: Oxford University Press, 1975). On Thomas and Berthold de Villiers, Philipp Fievet, Samuel Browne and Adrian Wyngaerden see Christoph Reske, Die Buchdrucker des 16. und 17. Jahrhunderts im deutschen Sprachgebiet (Wiesbaden: Harassowitz, 2007), 125, 262, 362-364. Both Browne and Wyngaerden had printing offices in Heidelberg, The Hague, and Leiden; they introduced French, English, and Dutch works in Germany, and German literature in Holland. For example the works of Johann Michael Moscherosch published by Wyngaerden in Leiden. See e.g. Johann Michael Moscherosch, Les Visions De Don De Quevedo. Das ist: 
Wunderliche Satyrische unnd Warhaftige Gesichte Philanders von Sittewaldt: In welchen Aller Welt wesen/aller Menschen Händel offentlich auff die Schaw geführet/alß in einem Spiegel dargestellet/ und von männiglichen gesehen werden. In fünff Theilen begriffen/ Und jedem Theil sein Register beygefügt (Leiden: Van Wyngaerde, 1646-1647). On Von Wiering, see Reske, Die Buchdrucker des 16. und 17. Jahrhunderts, 342-343. Von Wiering was particularly important for introducing new English literature, such as Defoe's Robinson Crusoe, to a German audience. See Wittmann, Geschichte des deutschen Buchhandels, 96.

${ }^{59}$ Burke, Lost (and Found) in Translation, 11. See also Peter Burke, "The Renaissance Translator as GoBetween," in Renaissance Go-betweens: Cultural Exchange in Early Modern Europe, ed. Andreas Höfele and Werner von Koppenfels (Berlin: De Gruyter, 2005), 17-31.

${ }^{60}$ On the role of the first generation of French and Netherlandish migrants as cultural intermediaries in Frankfurt and Cologne, see also Cornel Zwierlein, "Kommunikationsräume und Erinnerungsräume in Migrantenmilieus. Exil- und Kriegserinnerung im Köln des 16. Jahrhunderts," in Europäische Erinnerungsräume, ed. Kirstin Buchinger and Claire Gantet et al. (Frankfurt: Campus, 2009), 119-131; Michiel van Groesen, "Entrepreneurs of translation: Latin and the Vernacular in the Editorial Strategy of the De Bry Publishing House" in Translating knowledge in the early modern Low Countries, ed. Harold J. Cook and Sven Dupré (Berlin: Lit., 2013), 107-128.

${ }^{61}$ George Hartlib, Georgii Hartlibii Exulis Diarium Christianum: Das ist Ein Hand-Büchlein/Darinnen gezeiget wird wie man täglich sein Christenthumb zu Gottes Ehren/ und zu seiner selbst eigenen Wolfahrt recht führen und werckstellig machen solle (Amsterdam: Hans Fabel, 1648); Anon. (Hans Fabel?), Dialogus Oder Gespräch/ einer hungerigen/dürstigen Seelen/nach der Quell des Lebens (der süssen Liebe Jesu Christi) und einer Erleuchteten Seelen: Auff was weise ein Seele die andere suchen/trösten/ und zu ihrer Erkändtnuß/auff die Pilgram-Strasse Christi führen/ und ihr den dornichten Weg der Welt/der in Abgrund führet/darauff die abgewandte Seel wandelt/trewlich zu einem Spiegel vor Augen gestellet (Amsterdam: Hans Fabel, 1649). 62 Douglas Shantz, "Homeless Minds: The Migration of Radical Pietists, their Writings, and Ideas in Early Modern Europe," in Pietism in Germany and North America 1680-1820, ed. Jonathan Strom, Hartmut Lehmann et al. (Farnham: Ashgate, 2009), 85-100. See also Jonathan Strom's introduction to this volume.

${ }^{63}$ On literary cultural exchanges between Germany and the French and Dutch language areas, see e.g. Marcel Krings and Roman Luckscheiter, eds., Deutsch-französische Literaturbeziehungen. Stationen und Aspekte dichterischer Nachbarschaft vom Mittelalter bis zur Gegenwart (Würzburg: Königshausen \& Neumann, 2007); Jan Konst, Inger Leemans and Bettina Noak, eds., Niederländisch-Deutsche Kulturbeziehungen 1600-1830 (Göttingen: V\&R Unipress, 2009). For an overview over Dutch-German literary exchange in the seventeenth century, see also the introduction in Bundschuh-van Duikeren, Bibliographie der niederländischen Literatur in deutscher Übersetzung, IX-XX. 